\title{
CRIMINOLOGIA MIDIÁTICA E A CAMPANHA “CRACK, NEM PENSAR”: REFLETINDO SOBRE A FALTA DE PENSAMENTO
}

\section{MEDIA CRIMINOLOGY AND THE CAMPAIGN “CRACK, NEM PENSAR”: REFLECTING ON A LACK OF THOUGHT}

\author{
Guilherme Michelotto Böes \\ Sociedade Brasileira de Sociologia - SBS - (Porto Alegre, RS, Brasil) \\ Augusto Jobim do Amaral \\ Pontifícia Universidade Católica do Rio Grande do Sul - PUCRS - (Porto Alegre, RS, Brasil) \\ Recebimento: 17 out. 2018 \\ Aceitação: 27 dez. 2018
}

\begin{abstract}
Como citar este artigo / How to cite this article (informe a data atual de acesso / inform the current date of access):
BÖES, Guilherme Michelotto; AMARAL, Augusto Jobim do. Criminologia midiática e a campanha "Crack, nem pensar": refletindo sobre a falta de pensamento. Revista da Faculdade de Direito UFPR, Curitiba, PR, Brasil, v. 64, n. 1, p. 63-95, jan./abr. 2019. ISSN 2236-7284. Disponível em: <https://revistas.ufpr.br/direito/article/view/62382>. Acesso em: 30 abr. 2019. DOI: http://dx.doi.org/10.5380/rfdufpr.v64i1.62382.
\end{abstract}

\section{RESUMO}

Qualquer abordagem criminológica que pretenda refletir sobre a mídia deve ter, entre as suas preocupações centrais, os processos que capitalizam tais meios mediante as imagens que propagam na elaboração das suas construções sociais. Neste aspecto, talvez o campo da política criminal de drogas seja um dos mais privilegiados, em especial desde a análise da montagem das figuras associadas aos usuários de certas drogas tornadas ilícitas, bem como em relação aos mecanismos de controle seletivo que neles recaem. Para tanto, nesta linha, buscamos compreender a campanha chamada “Crack, nem pensar", veiculada pelo Grupo RBS em 2009, como representante da enorme força simbólica e do impacto que tais plataformas podem trazer diante das demandas proibicionistas. Apresentando os desdobramentos desta dinâmica publicitária, constatam-se os efeitos de exclusão social e demonização de determinados grupos sociais dispostos como alvos da peça, numa franca cruzada moral de guerra às drogas, a despeito dos estudos científicos mais apurados sobre a falência de tal política.

\section{PALAVRAS-CHAVE}

Criminologia. Política criminal. Drogas. Mídia.

\begin{abstract}
Any criminological approach that seeks to reflect on the media must have, among its central concerns, the processes that capitalize such media through the images they propagate in the elaboration of their social constructions. In this regard, perhaps the field of criminal drug policy is one of the most privileged, especially since the analysis of the mounting of the figures associated with the users of certain illicit drugs, as well as with the selective control mechanisms that fall within them. In order to do so, we aim to understand the campaign called "Crack, nem pensar", presented by the RBS Media Group in 2009, as representative of the enormous symbolic force and the impact that such platforms can bring to the prohibitionist demands. The effects of social exclusion and demonization of certain
\end{abstract}


social groups that are set forth as targets of the play, in a frank moral crusade of drug war, are evident, despite the scientific, more accurate studies on the bankruptcy of such policy.

\section{KEYWORDS}

Criminology. Criminal policy. Drugs. Media.

\section{INTRODUÇÃO}

Abordar a campanha “Crack, nem pensar”, vinda a público em 2009 e veiculada pelo Grupo RBS apresenta-se como um caso de excelência quando o assunto atravessa os estudos criminológicos em comunhão com a análise dos meios de comunicação de massa. Considerando que a mídia constrói sua plataforma discursiva de maneira considerável no corpo social e tem influência profunda quando estão em cena os processos de criminalização prontos a alavancar o debate proibicionista em matéria de substâncias ilícitas, fundamental será lê-la como instrumento privilegiado no controle penal seletivo.

Se a criminologia, como escreve Vera Andrade, diante da sociedade, deve assumir seus saberes na direção da compreensão e limitação da violência que a cerca, buscando modelos alternativos à função social do direito penal (ANDRADE, 2012), espaço singular é a reflexão sobre uma campanha midiática que usa imagens ostensivas no debate sobre certa substância tornada ilícita, quer dizer, peculiar valor haverá em perceber tais discursos a partir de uma visão criminológica crítica, delineando a própria atuação da (des)informação como recurso criminológico na direção de pautas de enfrentamento político criminal.

Nesta direção, portanto, para abordar a campanha “Crack, nem pensar”, faz-se necessário antever desde logo o quanto o gerenciamento da peça aderia a um claro mecanismo de exclusão social, propriamente por meio da estigmatização dos sujeitos envolvidos com o crack. Não apenas desde a explícita negação da reflexão - presente inclusive no slogan "nem pensar” -, mas abdica de examiná-lo com a necessária seriedade, nublada pelo proibicionismo, optando pelas formas sociais taxativas de pânico e enfretamento patológico criminalizante, sempre dispostos a incrementar inclusive a repressão policial.

Marília Budó (2016), a partir da concepção de Barak (1988) de Newsmarking Criminology, ao interrogar como os criminólogos devem enfrentar a questão da reprodução da mídia sobre crime e violência, sabendo que os grupos de comunicação de massa em geral possuem pautas quase que exclusivamente conservadoras acerca da questão penal, esclarece que devemos ultrapassar o discurso ideológico e refinado da mídia e, como tentaremos aqui apontar, considerar criminologicamente a 
elaboração dos discursos de representação imaginária dos usuários de drogas. Se, como salienta Hart (2014), por um lado, o usuário de maconha já não é exclusivamente o negro e morador do gueto, bem como o usuário de cocaína sempre esteve presente nas classes mais altas, no fim das contas, por outro lado, atualmente o discurso contra as drogas vem mudando, pois a transitoriedade do consumo delas em diferentes grupos sociais faz com que se construa uma pauta como que para encontrar um denominador do seu usuário.

Sendo assim, o trabalho pretende enfrentar o problema da montagem midiática da realidade político-criminal no tocante às pautas estigmatizantes quando se trata de veicular uma campanha publicitária relativa ao uso de crack. Metodologicamente, o recorte pretende ir ao encontro da análise de imagens veiculadas pelo Grupo RBS, de maio de 2009 ao final do ano de 2010, buscando identificar o discurso presente sobre “Guerra às Drogas” e “epidemia do crack”. Portanto, foi realizado um levantamento prévio das notícias a partir da leitura do Jornal “Zero Hora”, a partir de recortes das manchetes e capturas de tela no âmbito digital. Para acompanhar essa ampla análise diária e conseguir fazer uma melhor seleção das imagens disponíveis, foi necessário pesquisar no banco de dados do arquivo digital da referida empresa midiática. Utilizando termos como "Crack" e “Drogas”, apurou-se um número de mais de 1.500 matérias entre os anos de 2009 e 2010. A referida seleção dessas palavras baseou-se nos estudos e vetores que vêm sendo discutidos por algumas das principais pesquisas acadêmicas (ALVES, 2010; BATISTA, 2003; CARVALHO, 2010; DOMANICO, 2006; INÁCIO, 2009; entre outros) sobre o tema. Assim, a estrutura do trabalho primeiro dirige-se a apresentar sua base teórica desde uma aproximação criminológica que tenha como foco os meios de comunicação de massa, permitindo, logo após, adentrar no exame da campanha em si - “crack, nem pensar” - para, em momento final, verificar como se deram as estratégias midiáticas de exclusão social diante das figuras dos usuários ali envolvidas.

\section{CRIMINOLOGIA E MÍDIA}

Quando em seu conjunto de conferências chamado “As palavras dos mortos”, Zaffaroni (2011) salienta o que seria, a seu ver, uma criminologia midiática, frisa o seu descompasso com a dita criminologia acadêmica. Aquela cria uma realidade por meio da informação, subinformação e desinformação com base em soluções simples para os problemas criminais. Como já alertava Gregg 
Barak (1988), tais panaceias acabam por ser vendidas diretamente pela construção social do crime e do desvio e diretamente amparadas pela formação política e ideológica da mídia.

Assim, caberia aos criminólogos aproximarem suas críticas do sistema, adequando sua linguagem e tornando-a mais acessível a toda população. Desta forma, teríamos a possibilidade crítica de contextualizar os preconceitos na seleção do crime e do criminoso. A constante exposição da violência em diversas mídias reforça a ideia de que as fronteiras entre real e virtual estão cada vez mais tênues, nada disso diferenciando-se da concepção das novas mídias baseadas na internet. Não obstante, deve-se compreender ainda mais o funcionamento destas plataformas como prática social, o que se poderia chamar de "experiência da internet”: espaço em que as categorias "real” e "virtual”, além de se (com)fundirem, tornam-se centrais para a representação da vida cotidiana. Em “loops”, pelos quais montam processos contínuos de significação e ressignificação permanentes, as imagens são reproduzidas em contínuo espelhamento, no que podemos chamar de hall of mirrors. Nesse contexto, a noção de crime, sistema penal, violência, por vezes é confundida com sua própria representação, de modo que a compreensão entre o real e o imaginário se encontra cada vez mais pulverizada.

\begin{abstract}
Independentemente da metáfora ["mídia rotativa" ou "sala de espelhos"], cada um capta algo do mesmo processo: uma fluidez cultural circulante que supera qualquer distinção precisa entre um evento e sua representação, uma imagem mediada e seus efeitos, um momento criminoso e sua construção dentro de um significado coletivo. [...] pretendemos sugerir um mundo moderno tardio em que a realidade arenosa, no terreno, do crime, da violência e da justiça cotidiana é perigosamente confundida com a sua própria representação.

A fluidez da cultura contemporânea não apenas acompanha o significado do crime e da criminalidade; volta atrás para amplificar, distorcer e definir a experiência do crime e da própria criminalidade. Em tais circunstâncias, o crime e a cultura permanecem irremediavelmente confundidos - e, assim, qualquer criminologia destinada a dar sentido ao crime e controle contemporâneos e a mover essas circunstâncias para possibilidades progressivas não pode fazê-la isolando artificialmente aquilo a que está intimamente e inevitavelmente entrelaçada. (FERRELL; HAYWARD; YOUNG, 2008, p. 130, tradução nossa).
\end{abstract}

Com base em modelo comunicacional de análise do conteúdo midiático, essa criminologia trata o seu conteúdo midiático - palavras, parágrafos, figuras, imagens - como um texto a ser analisado, pronto a constituir uma política penal disposta a atingir determinado público. Esse modo de refletir concentra-se na avaliação da quantidade possível de influência sobre o telespectador, a partir da modulação de realidade por aspectos a serem debatidos e apresentados. As campanhas midiáticas sobre o crime e o criminoso formam cruzadas publicitárias diárias sugerindo estereótipos sociais aos seus consumidores. Vendendo imagens irreais sobre usuários de drogas, com campanhas securitárias e televisionamento de dramas, essas imagens manufaturadas da violência promovem um 
código mundial de fissura social, de classes e étnico racial. Um debate público sobre a questão criminal filtrando o crime como um produto a ser vendido e o criminoso como uma patologia a ser enfrentada pelo endurecimento punitivo sempre legitimou o poder punitivo, sobretudo atualmente, quando uma razão neoliberal governa um contingente humano de refugos sociais.

Dessa maneira, o contexto bélico de combate às drogas (tornadas ilícitas) não cessa de ser apresentado. Não raro, restringe-se ao que poderíamos chamar de “argumento Tropa de Elite”. Naturalmente, atinente ao block buster nacional, o discurso desliza pela ideia débil de atribuição de culpa ao usuário de drogas que, afinal, ele “financia esta p... toda” (dirá o protagonista). Quer dizer, falácia da culpa dos consumidores que alimentaria a violência, produto em realidade exatamente do processo de criminalização, da política proibicionista em si. Pouca responsabilidade há em deslocar o foco da guerra a (certas) pessoas que é travada neste cenário para sustentar um bode expiatório que nubla a questão de fundo: vez mais é o proibicionismo que desencadeia a violência provocada pela criação do campo do ilícito e não qualquer suposto consumidor que sempre haverá independentemente da criminalização.

Ademais, desde a passagem do século XIX ao XX tem havido uma intensa intervenção no campo das drogas, operada por um imenso aparato de intervenção, regulação dos hábitos e cotidianos da população, principalmente a partir de políticas sexuais e raciais. Esse processo tem consequências na seletividade e criminalização da pobreza (ROSA, 2017). Assim, os sistemas da mídia (con)formam suas posições da ordem social por exercícios diários de poder, representando jovens e moradores de periferias como consumidores de drogas e legitimando não somente a seletividade do sistema penal, mas a indução de bodes expiatórios pela necessidade de controle e espetacularização do caos criminal (BUDÓ, 2016).

Não são poucas as tentativas midiáticas de consolidar a imagem atávica do drogado atrelada a um parâmetro étnico e social. Hart (2014), por exemplo, aponta tal vinculação desde manchetes do ano de 1900. Ou seja, no início do século XX, a preocupação da mídia estava diretamente relacionada com a cocaína, como no caso por ele destacado àquela época: "NEGROS VICIADOS EM COCAÍNA são uma nova ameaça no Sul”. E essa própria mídia trata de retratar negros como ameaças por ficarem “loucos” ao usarem cocaína (HART, 2014, p. 231-233; grifo do autor).

As palavras dos mortos teimam em ser silenciadas pela mídia. A similaridade entre as mais variadas campanhas midiáticas mostra como há, a rigor, um “encobrimento” do assunto das drogas, sobretudo dos seus efeitos sobre as pessoas. A reprodução de argumentos da ordem de uma biologia criminal do século XIX em matéria criminal não impede que a mídia propague seu poder no tempo e espaço e, em que pesem outras formas de tecnologias comunicacionais (ZAFFARONI, 2011, p. 365 
et seq.), permanece como uma forma de poder cultural de enorme conteúdo simbólico. A produção da notícia, portanto, o News, também o perpétuo novo (o new ${ }^{1}$ deve ser compreensível em todos os tipos de interações, seus meios e materiais de transmissões, de modo a alcançar o caráter simbólico da vida social.

A mídia, como formidável instrumento de manutenção da ordem simbólica, em que informação e conteúdo simbólico são produzidos, acaba por estruturar os meios pelos quais os indivíduos se relacionam entre si. Trata-se de uma forma de ação simbólica que provoca reações, libera respostas de determinado teor, sugere caminhos e decisões, induz a crer e a descrer, apoia os negócios do Estado ou pode mesmo sublevar as massas em revolta coletiva (BOURDIEU, 1997).

Diante do compreensível e visível novo, o já conhecido é experimentado como algo fora do comum, sem a menor compreensão do que seja notícia (news) e mais ainda do que novo (new). O material exige um consumo midiático desenfreado sem sua real significação na sociedade.

Quando os indivíduos codificam ou decodificam mensagens, eles empregam não somente habilidades e competências requeridas pelo meio técnico, mas também várias formas de conhecimento e suposições de fundo que fazem parte dos recursos culturais que eles trazem para apoiar o processo de intercâmbio simbólico. Estes conhecimentos e pressuposições dão forma às mensagens, à maneira como elas as entendem, se relacionam com elas e as integram em suas vidas (THOMPSON, 1995, p. 29-30).

Essas ações simbólicas - por exemplo, imagens televisivas, comunicação por meio de rádio, jornal, websites de forma altamente aleatória e para variados tipos de indivíduos - promovem um intercâmbio simbólico no espaço-temporal da comunicação pelas codificações e formas de aceitação das mensagens pelos indivíduos (THOMPSON, 1995).

A mídia faz ver para crer de forma a manifestar um poder com efeitos de mobilização. Apresenta a possibilidade da existência de representações e grupos, dentro dos mais variados incidentes ou acidentes cotidianos. Essas representações carregadas de implicações políticas e éticas são capazes de desencadear um aparato sentimental negativo, tais como racismo, xenofobia e medo/ódio do/ao outro (TIMM, 2015). Esse formato de relatar - “News” - implica uma construção social do presente, capaz de exercer efeitos de mobilização ou desmobilização. Ela produz a

\footnotetext{
1 "Notícias em inglês são chamadas de news. A visita de Estado de ontem não se encaixa mais hoje nas news, mesmo que nem todos se tenham inteirado dela, a não ser que tenha resultado em um escândalo e que leve a desdobramentos que por sua vez só possam ser entendidos se remetidos a ela. Ser, porém, meramente nova não é suficiente. O novo tem também que ser compreensível. [...] Sua novidade é, assim, compreensível apenas na medida em que haja uma capacidade de apreensão para ela: algo já conhecido, confiável, em relação ao qual poderá ser experimentada como se sobressaindo seja o conhecimento que se necessita ter para julgar uma luta de boxe, um concerto ou uma teoria como fora do comum, seja a capacidade para empatia que faz com que acidentes aéreos ou terremotos possam ser vistos como algo que pode acontecer a qualquer um, seja a familiaridade para com a região mais próxima, na qual a imprensa local aposta quando noticia sobre o assalto no novo bairro ou sobre a missa de calouros na igreja matriz. [...]” (TÜRCKE, 2010, p. 16).
} 
catástrofe, na comunicação de imagens atrativas impactando a esfera emocional a partir do que seria o “concreto”. Formam “sínteses de catástrofes que impressionam, mas que não dão espaço à reflexão” (ZAFFARONI, 2011, p. 369, tradução nossa).

A mídia, portanto, assume o binarismo produzido pelas formas subjetivas, com aval de um positivismo criminológico que apresenta o controle penal como instrumento redutor da alteridade, numa espécie de apartheid alheio a qualquer ação construtiva para uma sociedade plural (ZAFFARONI, 2011, p. 87-116). Baseado nesse sistema construtivo de apartação entre homem e mulher, rico e pobre e preto e branco, esse enfoque aduz a via criminal como base social da exclusão. A elaboração dessa "engenharia social moderna” em apontar os puros e impuros da sociedade aposta em uma ordenação de classificação binária:

Classificar, assim, consiste nos atos de incluir e excluir. Cada ato nomeador deve reduzir, ao final, a uma estrutura binária: entidades que respondem ao nome e o resto que não. Esse ato sempre comporta certa violência e requer uma dose de coerção. O paradoxal é que a luta contra a ambivalência é autodestrutiva e autopropulsora: ela prossegue com força incessante porque cria os próprios problemas a resolver (PINTO NETO, 2012, p. 83, grifo do autor).

O enfrentamento das questões penais, tais como a dita "guerra às drogas", combate aos “crimes de rua” como furto/roubo, desmilitarização das polícias, violência de gênero, etc. ainda continuam a ser mobilizados pelo modelo punitivo, perpetuando a ilusão da segurança pública nas políticas criminais do século XXI. Uma reflexão sobre esse Estado penal, além da mera ilusão, passa por uma crítica constante da ideia de enfrentamento à violência desde um Estado de Lei e Ordem, em que os humanos são alienados pelo poder de estabilização civil não raro mantido pelas campanhas midiáticas. Tais criminologias midiáticas sempre estiveram ancoradas em formas vingativas, em causalidades mágicas que reforçam as características de nossa civilização (ZAFFARONI, 2011).

Moysés Pinto Neto (2012) aponta um processo de engenharia social que condiciona a ideia de lei e ordem como requisito da totalidade, numa plena redução do desconhecido ao conhecido. Assim, aqueles que não se enquadram nas formas de "ordem” devem ser reduzidos e eliminados, pois representam a encarnação do perigo à lei e ao Estado (PINTO NETO, 2012, p. 121). Esse medo atua por adensamento midiático, tanto sob a atividade das forças de segurança quanto no próprio sistema punitivo como um todo. Esse resultado é o exercício dos poderes penais existentes na sociedade em função de ordem: a mídia, como (re)produtora do medo e da insegurança, solicita ao Estado a aplicação da segurança pública pouco responsável que resulta na expansão do controle penal e obedece às ilusões de uma criminologia positivista (ANDRADE, 2012, p. 162).

As significativas elevações dos registros de crimes violentos, a partir da década de 80, condicionou o avanço de uma política criminal conservadora, com o fomento de novas espécies de 
criminalização. Esclarece Salo de Carvalho (2010) que essas mudanças influenciam diretamente a questão criminal ${ }^{2}$. Esses fenômenos encontram na prática de um Estado penal punitivo as respostas para atribuição das responsabilidades amparadas na vontade de punir.

O sintoma contemporâneo vontade de punir, que atinge os países ocidentais e que desestabiliza o sentido substancial de democracia, propicia a emergência das macropolíticas punitivistas (populismo punitivo), dos movimentos políticos-criminais encarceradores (lei e ordem e tolerância zero) e das teorias criminológicas neoconservadoras (atuarismo, gerencialismo e funcionalismo sistêmico) (CARVALHO, 2010, p. 9, grifo do autor).

A crimiminologia crítica, ao denunciar a falência da intervenção estatal, tem a possibilidade de questionar estas estruturas que mantêm a sociedade sob fundamentos ideológicos produtores de desigualdade ${ }^{3}$. Logo, como faz Andrade (2012), ao relatar sobre a segurança pública brasileira desde o monopólio do Estado soberano e gerenciada pelo poder punitivo, percebe essas intervenções estatais no controle e seleção da punição não como um ato meramente legislativo e administrativo. Não se olvide que todas as agências do sistema penal têm uma grande influência nessas seleções.

Diversamente, são as agências dos Poderes Executivo (Polícia, Ministério Público e Administração Carcerária) e Judiciário (Magistratura), que estabelecem os critérios de interpretação (regras e metarregras) que definirão as formas de incidência do controle penal na sociedade civil (criminalização secundária) com a efetivação/obstaculização da política legislativa, aumentando ou restringindo o punitivismo (CARVALHO, 2010, p. 60).

Na manutenção dessa ordem, o sistema de justiça é padronizado e estigmatizante. As práticas conhecidas envolvem desde o preconceito por parte das polícias como dos próprios magistrados nas motivações de suas decisões. As constatações são conhecidas pela sociologia da administração da justiça penal. Dirá Rodrigo Azevedo:

As conclusões, em geral, apontam para a existência de uma dupla seletividade na atividade judiciária: seletividade na aplicação da lei, com maior probabilidade de punição para os setores sociais desfavorecidos economicamente e culturalmente, e de favorecimento para as classes superiores, e seletividade na interpretação da lei, com a utilização pelo juiz de seu poder discricionário segundo suas opções políticas e ideológicas (AZEVEDO, 2014, p. 397398).

Esse modelo de aplicação do sistema penal condiciona que as práticas de segurança pública sejam dispostas desde a defesa da ordem. Com números cada vez maiores de cidadãos no cárcere -

\footnotetext{
2 "Entende-se por questão criminal os fenômenos relativos às práticas delitivas e suas circunstâncias, ou seja, as formas de delito, seu modo de execução, as consequências que produz e grau de vitimização que provoca” (CARVALHO, 2010, p. 8, grifo do autor).

3 “O elemento ideológico não é contingente, mas inerente à estrutura e à forma de funcionamento do sistema penal, assim como este, em geral, é inerente à estrutura e ao funcionamento do direito abstrato moderno. A forma da mediação jurídica das relações de produção e das relações sociais na sociedade capitalista moderna (o direito igual) é 'ideológica': o funcionamento do direito não serve, com efeito, para produzir a igualdade, mas para reproduzir e manter a desigualdade.” (BARATTA, 2002, p. 213).
} 
depósitos humanos sem as mínimas condições de sobrevivência digna -, com o policiamento repressivo, cada vez mais privatizado [o controle é o seu próprio descontrole], as vítimas reproduzemse em escala industrial. Daí a fragilidade estatal, ante uma espetacularização da questão criminal, em se ocupar de qualquer iniciativa de inclusão social (ANDRADE, 2012, p. 177). As respostas simbólicas para os problemas sociais são capturadas pela criminalização, a partir do espetáculo midiático que aciona a criminalização e legitima as estruturas do senso comum.

As perigosas interpretações lançadas pela mídia por suas campanhas criminológicas espalham e alimentam o medo do outro e condicionam um caráter idealista de sociedade, em que seríamos meros espectadores de nossas “vidas diárias”. Não informam e descontextualizam as imagens para que não se possa refletir adequadamente sobre o que ocorre. Essa criminologia midiática cria a realidade de um mundo onde há pessoas decentes diante de uma massa de criminosos estereotipados e separados do resto da sociedade, exatamente por comporem um conjunto de “diferentes e maus” (ZAFFARONI, 2011, p. 369, tradução nossa).

Portanto, como salientado por Zaffaroni (2011), há uma criminologia midiática que se importa dos Estados Unidos. Uma criminologia pautada, em geral, para manter milhões de pessoas encarceradas. A “criminologia midiática do sul” tende a copiar e a caricaturar o que vem do norte, tende a traduzir com maior violência ainda o sistema penal como resposta (ZAFFARONI, 2011, p. 381). Em suma, cabe, ante este quadro, delineá-lo melhor. Para tanto, extremamente rico será analisar a performance criminológico-midiática estampada na campanha “Crack, nem pensar”, seus significados e preocupações punitivas.

\section{ESTUDO DE CASO: A CAMPANHA “CRACK, NEM PENSAR”}

O chamado “crack” já causa, imediatamente por seu próprio nome, repulsa e pânico. Valois (2017) destaca esta fonte de mitos como causada, em realidade, sobretudo, pelas características da miséria que já envolvem o próprio encontro das políticas repressivas com esta droga, marcadamente uma substância vinculada à exclusão social. Das ideias equívocas do "vício imediato" à imagem de “zumbis vagando pelas ruas”, a mídia forma seus olhares sobre grupos sociais vulnerabilizados.

Hart (2014) talvez esteja entre os mais preocupados cientistas em enfrentar o preconceito sobre o crack. Neurocientista, que inclusive já foi usuário de crack, assume que por muito tempo também acreditou nas campanhas midiáticas sobre os efeitos devastadores da droga. Resolveu, assim, testar empiricamente todas as falácias sobre as “drogas mais pesadas”. Identificou que o crack, como qualquer outra substância tóxica, não causa os efeitos propagados como incontornáveis pela mídia, 
inclusive alertando sobre a base falaciosa das campanhas sobre "epidemias" que recorrentemente se produzem. Já que os “meios de comunicação não aplicam esses métodos [análise de hipóteses e estatísticas sobre os usuários] ao noticiário, com frequência apresentam um quadro muito simplista e distorcido.” (HART, 2014, p. 236).

Então, entre os anos de 2009 a 2012, o grupo RBS (Rede Brasil Sul, sucursal da Rede Globo no Rio Grande do Sul e Santa Catarina) elabora e inaugura uma ampla campanha, intitulada “Crack, nem pensar”. Campanha que, no primeiro momento dos seus seis meses (28 de maio a quatro de dezembro) teve ampla cobertura publicitária, editorial e institucional. Essa primeira fase foi marcada pela difusão de fotografias, em que atores e atrizes “demonstravam” os estragos da droga causados no usuário. Grande parte da pauta dessa campanha foi apresentada a partir das imagens em que o usuário de crack é retratado como uma pessoa condenada à sarjeta, atirada ao relento, que perde toda família, amigos e dignidade.

O objetivo da campanha era durar um ano, mas, a partir da mobilização percebida, a campanha entrou em sua segunda fase publicitária, que assumiu mostrar como, a partir da campanha dos usuários (campanha anterior), há uma melhora na situação dos familiares e das pessoas próximas aos consumidores de crack. Os editoriais, a partir desse momento, retratavam pessoas que ajudavam os dependentes de narcóticos em tratamento. Em sua maior parte, a campanha amparava-se no argumento de que os dependentes são usuários de outras drogas e utilizavam o crack para sentir outra “sensação”. A campanha foi antes disponibilizada nos jornais de grande circulação e na comunicação audiovisual, estando as principais matérias e dados da campanha veiculados no site do grupo: http://www.clicrbs.com.br/especial/sc/cracknempensar/home,0,3710,Home.html ${ }^{4}$.

Em análise sobre a campanha, Petuco (2011) faz uma articulação entre o discurso da campanha e as descrições sobre as quais devemos pensar, isto é, ressalta as imagens apelativas contidas na formação do imaginário midiático que apresentavam os usuários de crack como pessoas destruídas por suas identidades e reduzidas a si mesmas. Essa foi uma forma de apresentar os usuários de drogas como pessoas incapazes e que “só pensam” em prejudicar as outras pessoas e obviamente cometer crimes. Com isso, ao observar e descrever a campanha, é possível identificar os discursos enunciados e questionar o que há por detrás dessa simbolização de discurso.

O que está sendo dito nestas campanhas? Que os usuários de crack são monstros perigosos, que habitam as sombras, a escuridão, os becos sujos, as escadarias, as calçadas. Desumanizados, são capazes de fazer sofrer às pessoas que os amam, roubando-lhes dinheiro,

\footnotetext{
${ }^{4}$ Acesso em maio de 2018.
} 
agredindo-as, negligenciando cuidados e carinhos, destruindo sonhos, desejos, anseios, desfazendo relações, traindo a confiança. Tudo por causa do crack (PETUCO, 2011, p. 117).

O ponto central da questão sempre escondido é, para além da identificação nefasta da condição do usuário, o que de fato o conduziu a este tipo de vida? Foi propriamente o crack ou a substância já é exatamente mais um elemento neste retrato de modo de vida precário? Em nada a campanha investe na análise da questão social que permeia o grupo de usuários deste tipo de substância na sociedade. E como bem alertado por Petuco (2011), um trabalho que pretenda analisar a questão das drogas jamais deve ignorar, sobremaneira, que diante de circunstâncias problemáticas, outras abordagens de redução de danos devem ser discutidas em face da política criminal.

Assim, foi diante dos mesmos supostos efeitos desta droga que o próprio Hart (2014, p. 245 et seq.) resolveu responder a partir de sua área de pesquisa neurocientífica. Seu estudo resolveu não usar apenas a administração de quantidade de drogas e constatar seus efeitos sobre animais. Utilizando o corpo humano para análise, verificou que as doses utilizadas em animais eram superiores ao que o corpo humano poderia aguentar. Seus resultados acabaram por demonstrar que o uso de entorpecentes como o crack está relacionado com as próprias condições sociais em que se encontram o usuário:

Pelo contrário, pude constatar que as pessoas viciadas não eram movidas pelas drogas. Além disso, não eram mais antissociais ou criminosas que muitas outras com as quais eu crescera, e que em grande parte nem ficava na doideira. Na verdade, o comportamento delas não era muito diferente do que eu mesmo adotava em meu meio, com meus amigos. Essas pessoas não pareciam totalmente dominadas pela ânsia de consumir drogas, elas buscavam recompensas através das drogas, da mesma forma como buscam sexo ou alimento. (HART, 2014, p. 248).

Hart conclui que determinante sobre os usuários de drogas é o ambiente cultural no qual se inserem, radicalmente distorcido pela acumulação de informações equivocadas em campanhas como esta, farta de preconceitos e estereótipos sobre certas minorias.

É importante apontar que substâncias entorpecentes como o crack, como escrevem Reinerman e Levine (1997 apud DOMANICO, 2006, p. 14-16), são uma derivação fumável de cocaína, que surgiu entre os anos 70 e 80 nos EUA, entre setores carentes da população negra e latina em áreas centrais de Nova York, Los Angeles e Miami. A produção prescindia do processo de purificação final: ao cloridrato de cocaína que era dissolvido em água, adicionava-se bicarbonato de sódio e aquecia-se a mistura, que, ao secar, adquiria a forma de pedras duras e fumáveis. Essas pedras continham não somente alcaloides de cocaína, mas também bicarbonato de sódio e todos os outros ingredientes que haviam sido adicionados anteriormente ao pó. 
O crack ao ser aceso libera um vapor que é em grande parte cocaína pura, produzindo um efeito parecido ao dela. Ele era geralmente produzido pelos próprios traficantes e vendido já pronto para ser fumado, logo tornando-se muito popular, embora seu uso não se tornasse tão comum quanto o do pó, o cloridrato de cocaína. Porém, devido ao fato de que fumar seria uma forma mais eficiente de levar a droga ao cérebro, a diminuição da quantidade de cocaína necessária para produzir um efeito forte possibilitou uma redução considerável no preço, tornando assim acessível às camadas mais pobres, diferentemente do uso da cocaína, até então considerada “o champanhe das drogas”. Esse produto também permitiu que se auferissem maiores lucros da pasta base que ainda chegava aos Estados Unidos para lá ser refinada e transformada em cocaína em pó. Mas, muitas vezes, os insumos químicos, como éter e acetona, necessários para a transformação da pasta base em cocaína, não estavam prontamente disponíveis devido ao controle governamental exercido sobre a sua comercialização. Para evitar maiores perdas financeiras, os traficantes passaram então a produzir essa forma menos pura, no entanto, mais facilmente vendável.

\begin{abstract}
Na verdade, o crack não é tão maravilhoso assim, nem tão superpoderoso em sua capacidade de recompensa. Ele alcançou popularidade no gueto (mais uma vez muito menor do que se costuma apregoar) porque não havia muitas outras fontes de prazer nem propósitos ao alcance dessas pessoas, e também porque muitos na faixa de altíssimo risco já apresentavam doenças mentais anteriores que comprometiam suas escolhas.

Por isso, ainda que os meios de comunicação tenham insistido durante anos em que era iminente a expansão do crack para outras classes, a droga nunca chegou a "devastar" os subúrbios afluentes nem a conquistar percentuais significativos de jovens de classe média ou alta. (HART, 2014, p. 261).
\end{abstract}

Hart (2014, p. 261) arremata que “as diferenças na prevalência dos problemas relacionados ao crack decorrem, sobretudo, das oportunidades econômicas, e não de particularidades da droga.”

Se se quisesse sustentar alguma "epidemia do crack”, ainda que de maneira errônea, naquele ou em qualquer momento, que fosse considerada, assim, seu ponto nevrálgico, ela seria o resultado da política proibicionista antidrogas, uma vez que a ausência dos componentes químicos “obrigou” os comerciantes de drogas a recuperar o investimento a partir do uso da cocaína fumada.

O nome crack, ao que tudo indica, deve-se ao barulho provocado pela "queima” da pedra durante o seu uso. Este subproduto da cocaína representava, de fato, uma inovação na produção. Era uma maneira de comercializar a cocaína, uma mercadoria cara e de prestígio, em pequenas unidades baratas. Apresentada dessa maneira, esse tipo de cocaína fumável era vendido nas ruas pela juventude negra e latina para uma nova clientela.

Seu sucesso deveu-se a vários fatores. Por um lado, havia um grande contingente de jovens desempregados dispostos a trabalhar no novo negócio de preparação caseira do crack e de vendê-lo 
em sua própria vizinhança. Era uma ocupação mais rentável que qualquer outro emprego disponível a eles, tanto na economia oficial quanto na criminosa. Além disso, essa inovação mercadológica, ao transformar a cocaína em pó em pedras fumáveis, mudava a maneira como a droga era consumida e reforçava de forma dramática a natureza da intoxicação pela substância, tornando-a rápida e mais intensa. Assim, o novo produto logo se tornou um grande sucesso de vendas e fonte de lucro para todos os escalões do tráfico. Nada perto disso, como necessário esclarecimento, passou perto da campanha “Crack, nem pensar”, fincada numa estética social de exclusão acompanhada pela repressão penal.

Conforme pesquisa organizada em conjunto pela Fundação Oswaldo Cruz (FIOCRUZ), o Ministério da Saúde e o Instituto de Comunicação e Informação Científica e Tecnológica em Saúde (ICICT) (BASTOS; BERTONI, 2014) sobre usuários de crack e drogas afins, de difícil contabilização, devido aos locais de acesso precário, o levantamento foi realizado por meio de amostragem de informações a partir dos espaços onde se “congregam” os usuários. Isso demonstra que o encontro se dá em lugares específicos que acabam por alimentar o imaginário social sobre o usuário. A própria pesquisa alerta que não se consegue mensurar todos os usuários, principalmente aqueles que fazem o uso da substância “em domicílios particulares ou instituições fechadas, como o sistema carcerário” (BASTOS; BERTONI, 2014, p. 29).

É importante destacar que este amplo estudo traz dados importantes, ao indicar que 52\% dos usuários de crack são não brancos, o que reforça a estigmatização e exclusão social que a própria mídia acabou por reforçar na campanha "Crack, nem pensar”. Constatou-se, pois, que uma das palavras mais recorrentes na campanha estava diretamente ligada ao conceito do uso de crack como “epidemia”, e que grande parte dos traficantes se passava por "usuários de drogas” (no plural) portando pequenas quantidades da substância para, em uma possível revista policial, serem enquadrados como usuário e assim se livrarem da prisão (ZERO HORA, 2009d, p. 34) (Figura 1). 
34

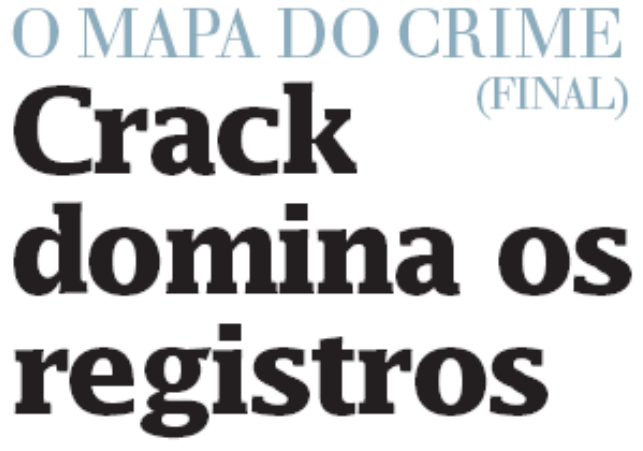

$63,6 \%$ dos casos envolvendo tráfico na Capital e atendidos pela BM eståo relacionados à pedra

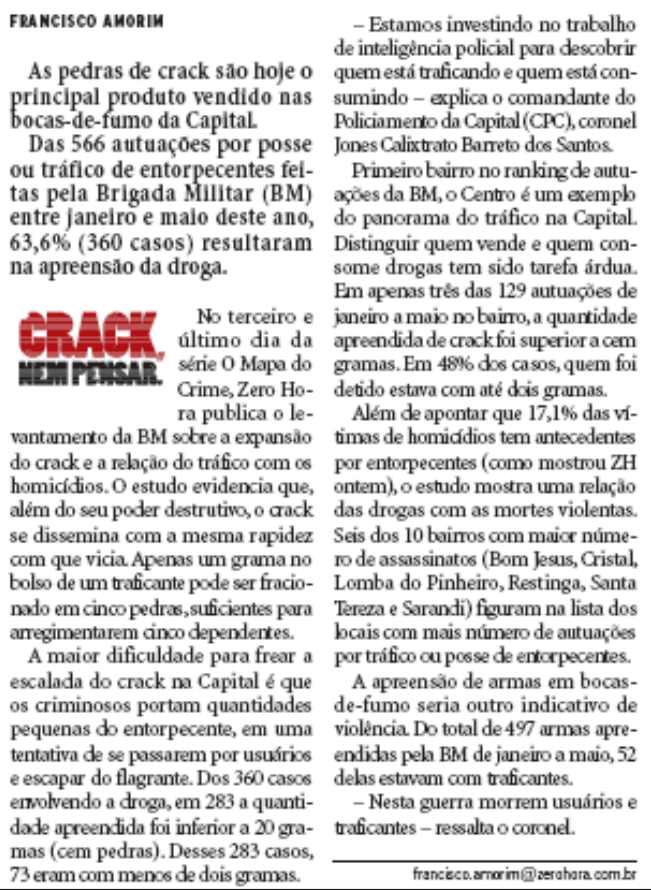

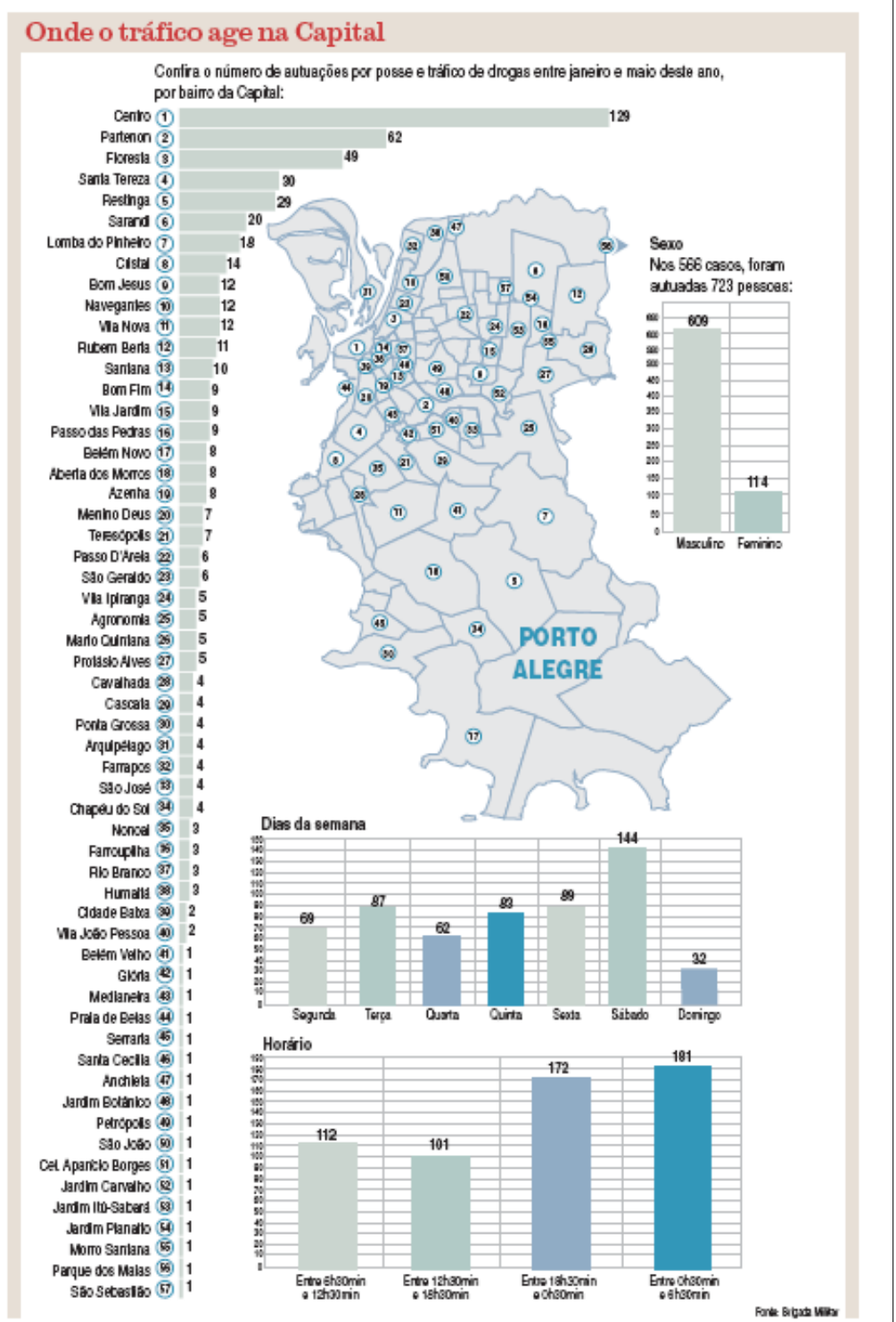

Fonte: ZERO HORA, 2009d, p. 34.

Em outra chamada da campanha, evoca-se um casal que "[...] foi arruinado pelo crack” e, logo abaixo, aparece a inscrição “fábrica de mendigos” (Figura 2). Mas, o que mais chama atenção na matéria é que o casal se “comporta” como tendo "consciência” de sua sobrevivência. Usam o crack em uma casa emprestada, e que estava abandonada, e tem uma vida a dois (como casal), trabalhando como recicladores - recolhem sucatas e papéis - para trocar por crack, o qual será compartilhado entre eles (ZERO HORA, 2009b, p. 38). 
Figura 2 - "Fábrica de mendigos"

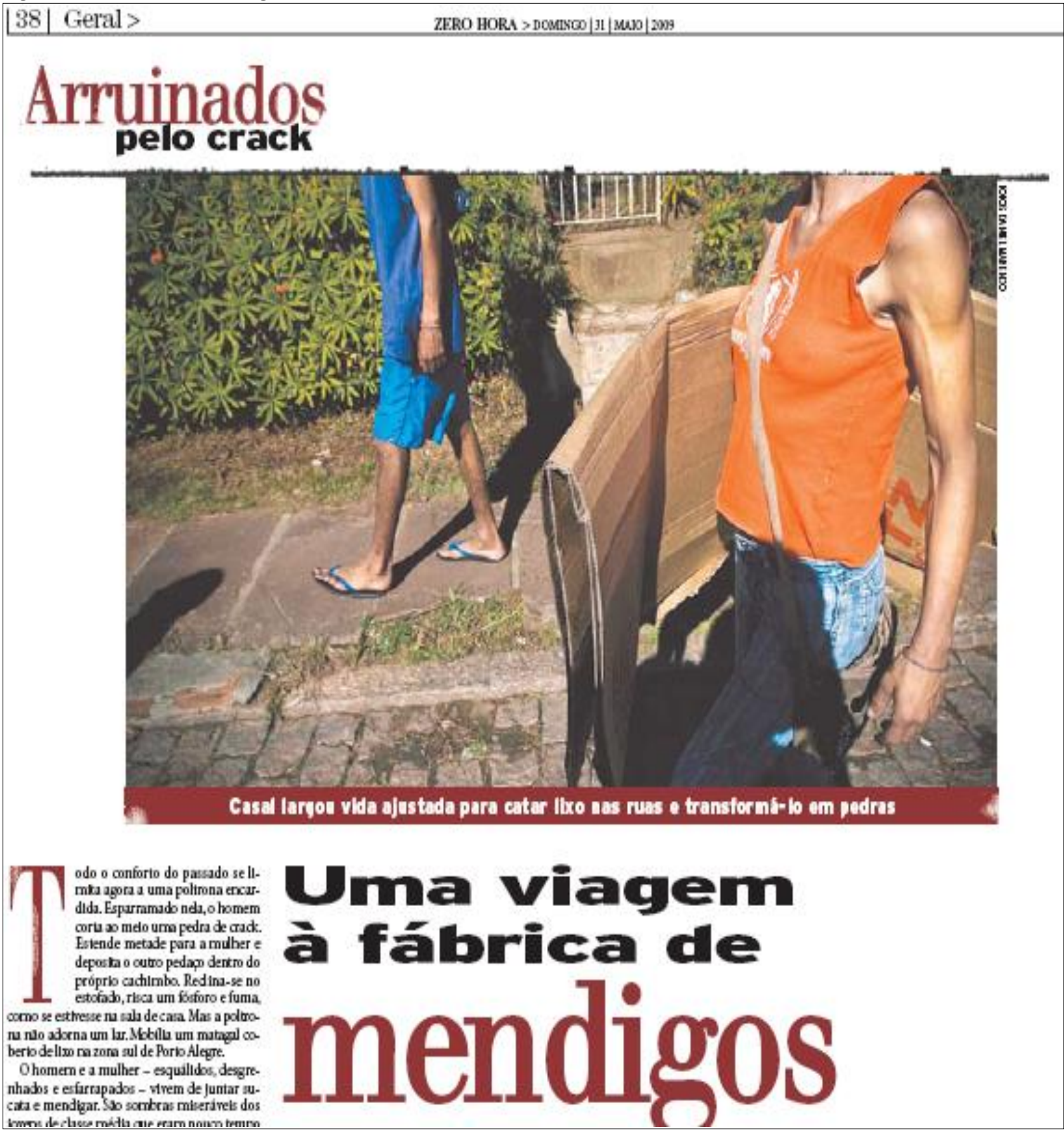

imms idechese math aie eram nnum trmm

Fonte: ZERO HORA, 2009b, p. 38.

É interessante destacar que, ainda no primeiro ano da campanha (2009), algumas matérias jornalísticas que se referiam à atuação policial de combate ao tráfico e ao uso de crack traziam consigo o slogan "Crack, nem pensar” associado diretamente à moralização do universo das drogas ilícitas em geral. Jogavam com um perfil estrito do dependente de crack, atrelando-os ao argumento da “porta de entrada” - quer dizer, o senso comum consolidado de que algumas “drogas leves” seriam meio de acesso facilitado para substâncias mais pesadas, falácia construída desde os anos 70 por pesquisas 
financiadas nos EUA por órgãos preocupados em justificar o proibicionismo (ZERO HORA, 2009c, p. 45) (Figura 3). 
Figura 3 - "Polícias ampliam ações antidrogas”

\section{BALANCO DESTE ANO Polícias ampliam ações antidrogas}

Levantamento mostra crescimento de $36,9 \%$ nas autuaçðes de traficantes

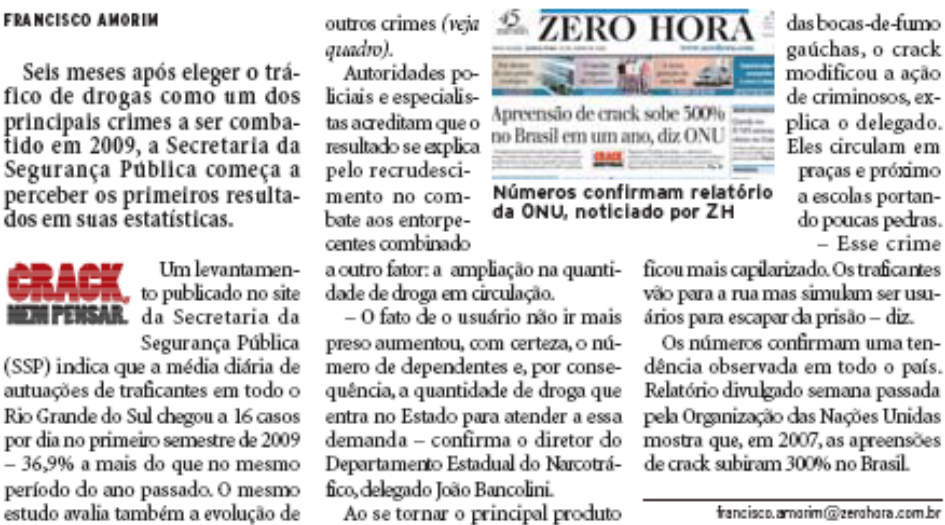

Os números da criminalidade

NO SEMESTRE
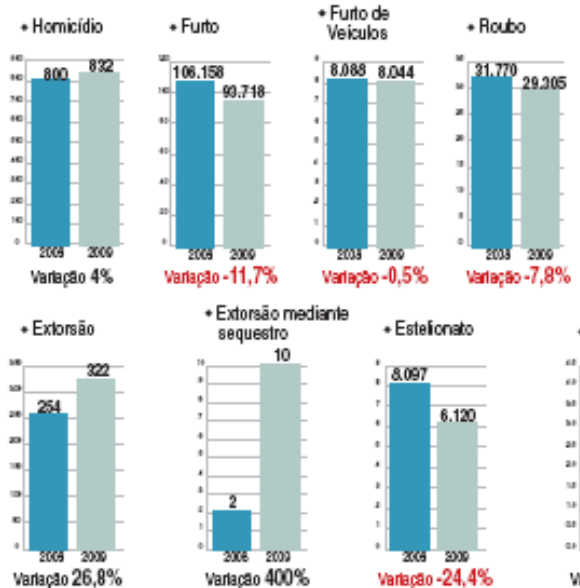

$$
\text { 7,8\% }
$$

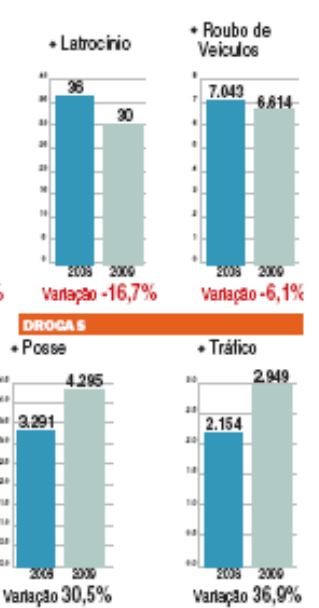

EM JUNHO
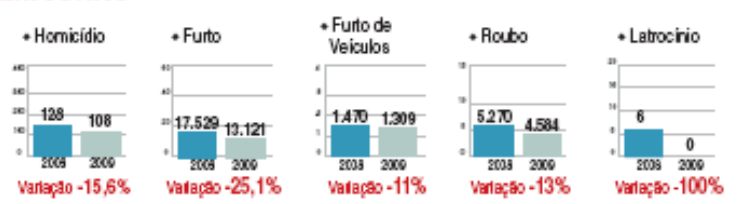

- Poubo de

Veisulce
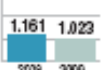

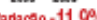

Valoz̧50 $-100 \%$

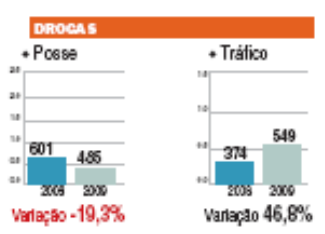

\section{Estado registra queda de roubo e furto de veículos}

Para os motoristas gaúchos, o le- especializadas em roubo e o cenánio vantamento da Secretaria da Segu- mudou já no início do segundo serança Pública traz uma boa notícia: mestre de 2008 - lembra o delegado os furtos e roubor de veículos estão Heliomar Francos titular da Delegacia em queda.Apesar disso, a média di- de Roubos de Véculos.

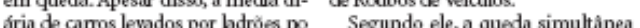
aria de canos levados por hadróes no Segundo ele, a queda simultanea Estado ainda se mantém alta. Scoo 81 dos dois crimes pode ser atribuida, automóveis e caminhcues que scmem em parte, à identificaçào dos badròes todos os dias - contra 84 casos no pri- que integravam as principais quadrimeiro semestre do ano passada A reduçào foi comemorada pelas tificaçào de criminosos que receptaautcridades policiais. Isso porque no vam os veicubo levados pelos ladrües segundo semestre do ano passado, também teria inibido os ataques. furtor (sem a presença da vítima)e A mudança na politica de barreiroubos (com ameaça ou violência ao ras da Brigada Militar (BM) também motorista) seguiam tendéncias opos- teria contribuído para a reduçáo dos tas. Enquanto caiam os registros de crimes. Blitze agora sấo realizadas assalto a motoristas, crescia o núme- em bcais onde șio registrados mais ro de carros furtados. casos de furtos e de roubos a partir

- Resolvemos atacar as quadrilhas de levantamentos diários.

CACCAPAVA DO SUL

Localizado jovem que vendia carne de cão

A Policia Civil de Caçapava do Sul sua identidade e o seu paradeiro nấo localizou, ontem, o jovem suspeito de foram divulgados vender carne de cachorro (como se Na terça-feira, quando a delegada fosse de porco ou de ovelha) a mora- Fabiane Bittencourt recebeu a condores do bairro Promoras. De acordo firmaçăo de que uma peça de came com o inspetor Gustawo Carlos Gon- encaminhada à perícia é mesmo de çalves, ele está internado em uma cachorro, policiais encontraram 21 clínica de reabilitaçào para se livrar carcaças de caes em um matagal do da dependência de crack no sul do bairmo Olocal que fica próximo a uma Estada. Para a segurança do suspeito, sanga, seria usado para o abate.

\section{PUBLICAÇÕES LEGAIS}
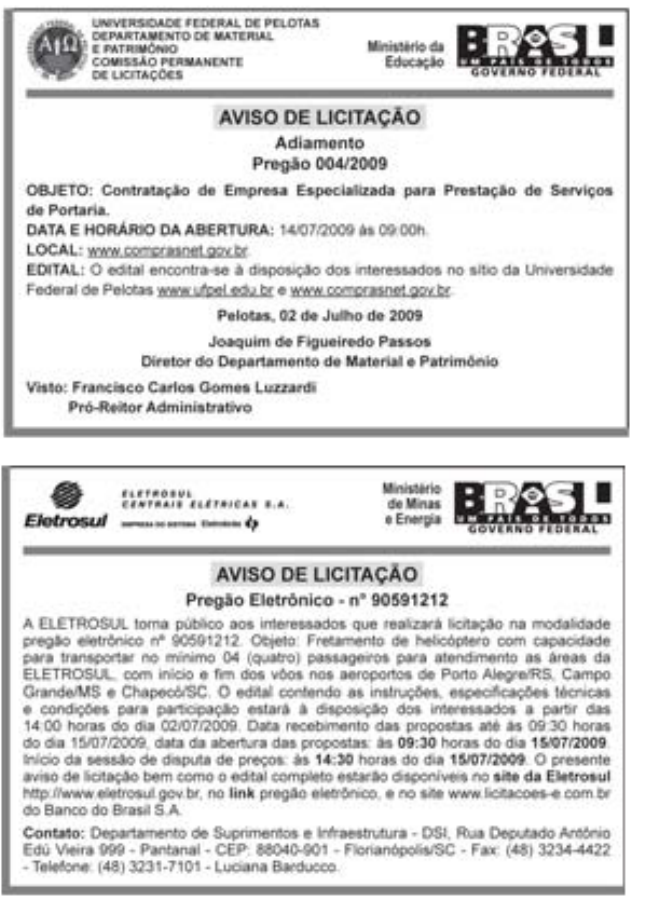

Fonte: ZERO HORA, 2009c, p. 45. 
Trata-se, noutros termos, da anuência ao "mito da escalada”. A insistência na existência de “drogas de passagem” que não se comprova cientificamente. Para começar, o usuário de crack é geralmente um poliusuário de drogas, isto é, utiliza simultaneamente uma combinação de diversas substâncias, como álcool, cocaína, maconha, solventes, etc. (DUALIBI; RIBEIRO; LARANJEIRA, 2007), e mesmo na Europa dois terços dos usuários de crack também utilizam heroína (EUROPEAN MONITORING CENTER FOR DRUGS ADDICTION, 2010) - em nada sendo comprovado que alguma delas seja caminho, etapa, ou relacione-se de forma causal a alguma outra droga mais potente.

Sabe-se que, como referido, tal movimento de política criminal proibicionista, que estaria respaldado cientificamente, em verdade foi produto do enfrentamento preconceituoso em relação à maconha. Esta falsa ideia trabalhava com uma burla ambiental, pois baseava seu estudo unicamente na análise de usuários de heroína para ligar ao consumo anterior de maconha.

É natural também que, como no caso do crack, tal universo de consumidores de heroína já tivesse feito uso desta substância (como de diversas outras), nada se preocupando a pesquisa em realizar as devidas comparações com um universo maior que fosse representativo do conjunto de usuários de maconha e, em consequência, o negativo desdobramento deles em substâncias tidas como mais pesadas (KARAM, 2009, p. 39). Em resumo, não resta dúvida da inexistência de qualquer respaldo científico que possa indicar vinculações entre consumidores de diferentes substâncias psicoativas determinadas pela composição de outras (GONZÁLEZ ZORRILA, 1983, p. 179-220).

A campanha, ademais, aderia plenamente ao receituário dos mesmos anos setenta (OLMO, 1998, p. 19-26), em especial aquele do governo republicano de Nixon, que inaugurou a chamada "guerra às drogas": absorver a plataforma dicotômica de "países consumidores” vs. "países produtores” de drogas (ZERO HORA, 2009a, p. 4) (Figura 4), que remanesce até hoje vitimizando países centrais em contraposição às intervenções militarizadas em países periféricos sobre o pretexto da repressão a determinadas substâncias ilícitas (BUSTOS RAMÍREZ, 1996).

Hart (2014, p. 27) também faz uma descrição da política que o ex-presidente dos Estados Unidos, Richard Nixon, programou. Uma política que "explorou o medo dos brancos e o ódio aos negros. Ela [a política implementada] transformou palavras como ‘crime’, ‘drogas’ e 'urbano' em códigos denotando 'negros', aos olhos de muitos brancos”, aumentando o índice de encarceramento de negros e a negação aos direitos civis. Este tipo de política alavancou a divulgação de uma política de drogas cada vez mais seletiva, associando a imagem do negro como condição de mau comportamento. Nesse sentido: 
Historicamente, no Brasil, as leis repressivas sobre drogas foram influenciadas pelo discurso médico mais do que por grupos religiosos, como ocorreu nos EUA. E foi somente a partir do século XX que o tema ganhou importância no espaço público nacional de discussão na perspectiva de "saúde pública” (BOITEUX, 2014). 
Ao final do primeiro ano, o grupo RBS apresentou os resultados percebidos, segundo eles, a partir da mobilização resultada da campanha: houve um aumento em $42 \%$ no índice de denúncias (“disque-denúncia”) no RS e 39\% em SC; o governo do RS destinou um milhão de reais para combate ao crack; houve aumento em 90\% do índice de apreensão de crack (2009 foi considerado o ano com maior índice de incineração de drogas no RS: seis toneladas, a maior repressão policial no combate às drogas nos Estados do RS e SC).

A campanha atingiu repercussão nacional, havendo logotipos da campanha no estado do RJ e notícias no jornal $O$ Globo. Tudo isto levou o grupo RBS a afirmar que a "ofensiva contra o crack ajudou a reduzir a criminalidade no Estado.” (ZERO HORA, 2009f, p. 41), propriamente como fruto da repressão e, sobretudo, desde a cumplicidade da comunidade na guerra contra o mal (Figuras 5 e 6 ). 
Figura 5 - Dados da Secretaria de Justiça e Segurança do RS - "Menos crimes”

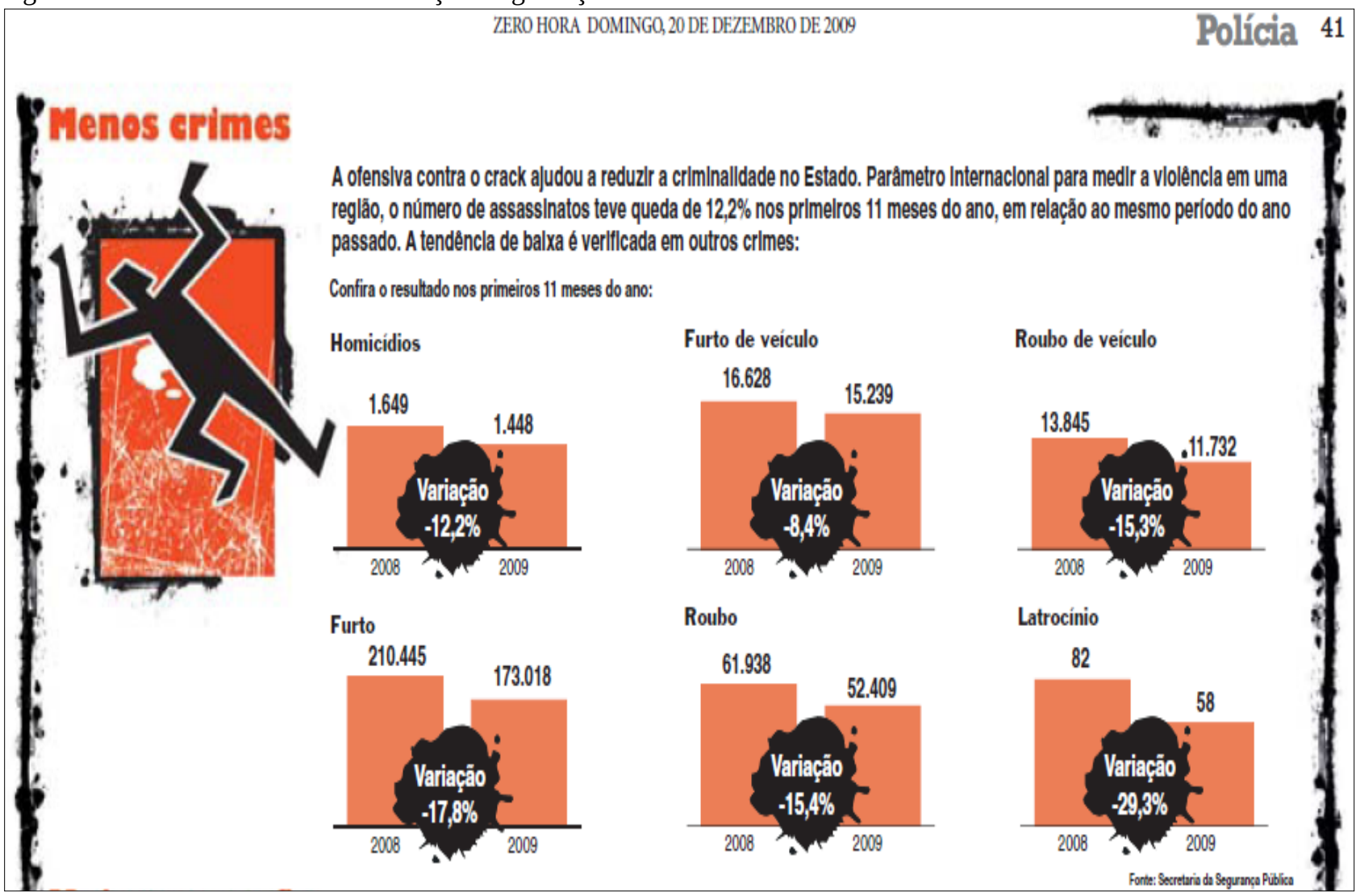

Fonte: ZERO HORA, 2009e, p. 41. 
Figura 6 - Dados da Secretaria de Justiça e Segurança do RS - "Mais repressão” e "Mudança de hábitos”

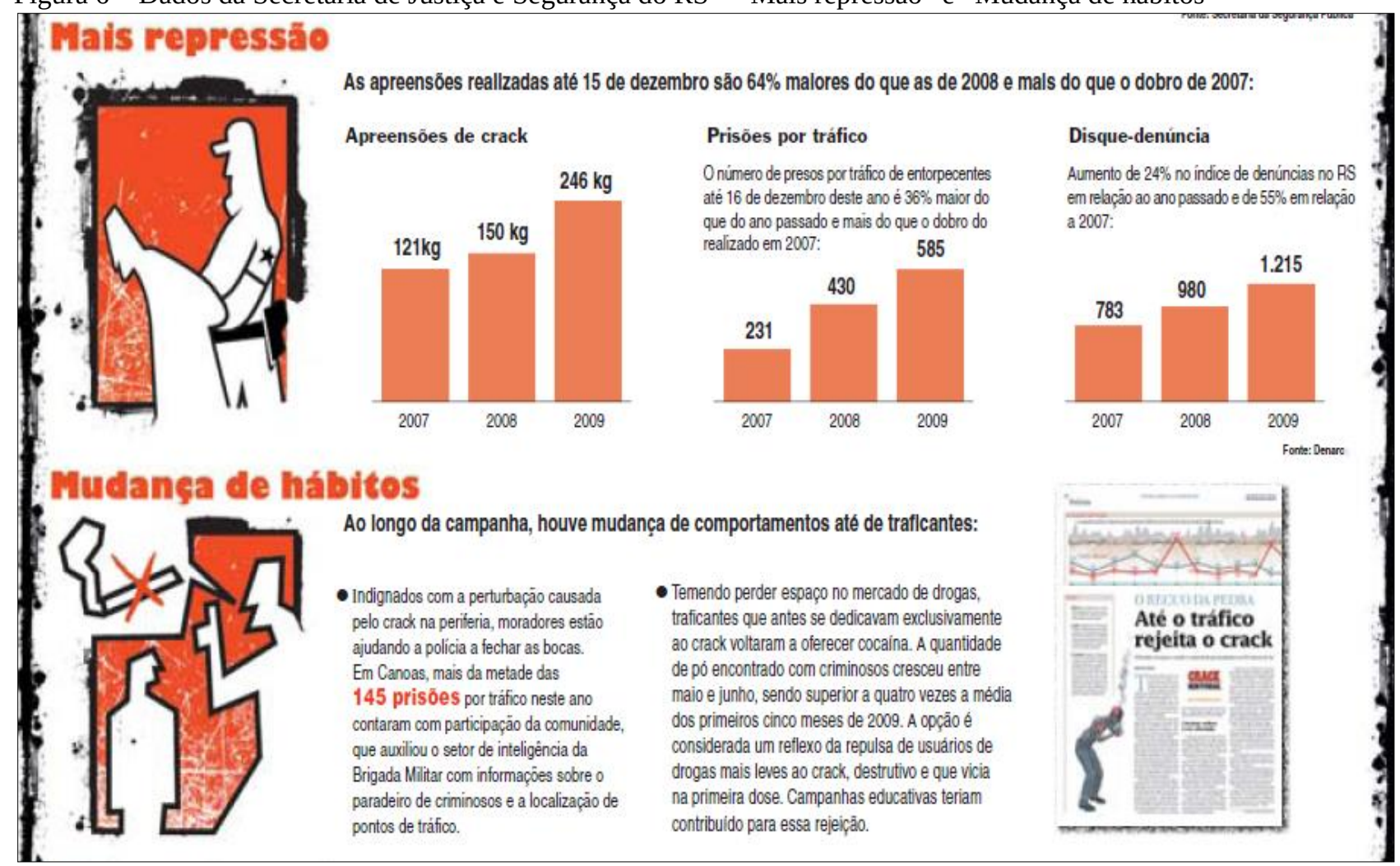

Fonte: ZERO HORA, 2009e, p. 41.

Vê-se claramente que, como aponta Batista (2002), mediante a atuação midiática no sistema de controle social, o sistema penal legitima-se permanentemente:

Este discurso aspira a uma hegemonia, principalmente sobre o discurso acadêmico, na direção da legitimação do dogma penal como instrumento básico de compreensão dos conflitos sociais. Este discurso habilita as agências de comunicação social a pautar agências executivas do sistema penal, e mesmo a operar como elas (executivização), disputando, com vantagem, a seletividade com tais agências. A natureza real desse contubérnio é uma espécie de privatização parcial do poder punitivo, deslanchando com muito maior temibilidade por uma manchete que por uma portaria instauradora de inquérito policial (BATISTA, 2002).

\section{GUERRA MIDIÁTICA E EXCLUSÃO SOCIAL}

As formas de seletividade utilizadas pelas políticas criminalizantes de ordem midiática, como já alertava Brownstein (1995, p. 45-79) quando estudava as publicações sobre drogas no período de 1986 a 1990 na mídia de Nova York, trabalham com um filtro de violências que amplifica aquelas causadas pelos usuários de drogas e se dirigem a destacar vítimas da classe média e pele branca. Não é nada estranho que tal programação literalmente funde-se na concepção ideal do seu público-alvo, claro que sempre amparada pelos “especialistas” de plantão. Carl Hart escreve que: 
No início da década de 1990, aumentou a preocupação quanto aos riscos oferecidos pelo crack, e muito dinheiro foi injetado na guerra contra essa droga. Não só inflaram os orçamentos dos organismos de ordem pública, como foram destinadas mais verbas para as pesquisas. Agora os cientistas participavam do jogo da histeria em torno do crack. (HART, 2014, p. 279-280).

Para a mídia realizar a representação dos malefícios das drogas, ela obtém informação com alguns profissionais prontos a sustentar os argumentos da publicação oficial sobre os dados de criminalidade, dando-se a impressão de um rigoroso esclarecimento para a população. Constrói-se conhecimento a partir da notícia para melhor relacionar a sua política de interesse. Controle de excluídos, portanto. A criminologia midiática reproduz e amplifica o discurso de que aqueles (outros) devem receber uma repressão maior, com maior segurança (para nós). Isso promove a expansão legitimada do poder punitivo, que continuará a se agravar o aniquilamento no contexto do "sul global” (ZAFFARONI, 2011, p. 381).

Se interpretações e fatos são coisas distintas, em que pese sua genética conexão (GUILHON, 2007, p. 40), a mídia, conforme Contrera (2002, p. 26), assim, torna-se a heroína de uma "sociedade sem heróis”, sedenta por instâncias que irão apresentar o discurso da salvação heroica na “tentativa de evocar as identificações e o poder simbólico-mítico do herói (poder esse que será, depois, muito convenientemente utilizado)”, que adquire um sentido que não corresponde absolutamente à realidade.

Dessa forma, ante a multiplicidade social brasileira, a mídia pretende a montagem de um cenário quase padrão e simplificador da "guerra às drogas", com a consequente demonização de classes, atrelada aos estereótipos e a constatações de pouca consistência. Viu-se na edição dominical de 15 de novembro de 2009 (ZERO HORA, 2009e, p. 36-37) a veiculação de que os EUA enfrentaram uma "grande epidemia do crack" e que o mesmo se passaria no Brasil.

No período retratado no caso dos Estados Unidos, havia 12 mil pontos de vendas em Nova York, que, para frear o avanço da pedra (crack), adotou a política de tolerância zero, levando à prisão milhares de traficantes e usuários, sem nem ao menos apontar qualquer crítica teórica ou empírica às falsas promessas do “Broken Windows Policing” (HARCOURT, 2004), iniciativa político-criminal que ajudou a produzir um encarceramento em massa nos EUA, com um profundo recorte racial (ALEXANDER, 2017), sem demonstrar em nada a conexão direta com a redução dos índices de violência.

Uma vez mais, a criminologia midiática atua como entretenimento e fonte de pânico moral, reafirmando a ideia de um mundo em guerra (ZAFFARONI, 2011, p. 384). 
Essa é a decorrência de um mundo de combate às drogas, um mundo onde a mídia atua conforme destaca Jock Young:

\begin{abstract}
A diversidade da modernidade recente evoca uma nostalgia do mundo inclusivo e seguro do passado; característico do período, o aumento da criminalidade e da desordem cria uma demanda de solução rápida, de uma panacéia para conjurar a volta das ruas e quintais seguros das memórias de infância. Papai está no trabalho (ou na guerra), mamãe em casa, o policial está fazendo a ronda, as violações são flagradas no nascedouro, e os delitos tratados com firmeza. Rebobine o filme: de volta para o futuro (YOUNG, 2002, p. 180).
\end{abstract}

Implica-se a produção midiática, neste sentido, a um discurso que é sempre mais violento que aquilo que pretende afugentar (XIBERRAS, 2006, p. 87-98), evocando um conjunto de processos psíquicos que provocam emoções com um profundo impacto em função do contexto social e da capacidade do sujeito para conferir-lhe um sentido (BARASCUT, 2006).

A força dos discursos do sistema penal, em especial os efeitos da imagem midiática da criminalidade, leva a uma espécie de desespero frenético que transfere indiferença à própria sociedade diante de si mesma. Transmitem um "processo de alarme social” que, manipulado pelas forças políticas em tempos de crise, no curso das chamadas campanhas de “lei e ordem”, leva à conservação do poder, produzindo a falsa representação de solidariedade que unifica todos os cidadãos na luta contra um “inimigo interno” comum (BARATTA, 2002).

Assim opera a criminologia midiática em sua seleção criminalizante:

O poder da criminologia midiática traduz-se na prática em um enfraquecimento da vigência
do Estado de direito. Debilita o poder político em função da autonomização das corporações
policiais e da antipolítica, mas também decidem com suas campanhas a seleção
criminalizante. (ZAFFARONI, 2011, p. 388, tradução nossa).

Noutros termos, realiza uma produção de fazer ver e, principalmente, de fazer crer no que se vê. Evocando um sentimento de mobilização, a publicidade apela a uma intoxicação do imaginário. Isto é possível mediante uma inscrição corporal e emocional dos sujeitos sobre os temas propostos (HOUDAYER, 2006).

A mídia, disposta a atuar no "problema” do consumo de crack, não parece querer compreender que criminalidade e desvio são processos culturais que se definem e se desenvolvem no interior de um mecanismo ideológico que tem lugar na reprodução da realidade social (BARATTA, 2002, p. 218). Esta seleção é relativa a cada sociedade de forma transversal e decidida desde parâmetros de suposta (a)normalidade social: “a média que define a norma. Quanto mais uma pessoa se distancia do status social mais comum, em um ou outro meio, mais cresce o risco de perseguição.” (GIRARD, 2004, p. 26-27).

Daí o reforço no poder que exerce a mídia, pois: 
Os meios de comunicação de massa desempenham um papel central na demonização: eles perseguem o desviante muito a frente à polícia, acusando-a freqüentemente de lidar inadequadamente com o caso. O sistema de justiça criminal fica assim na defensiva, em vez de estar em um papel moral empreendedor. (YOUNG, 2002, p. 171).

É evidente que, diretamente falando, serão estas instâncias que configurarão o poder normativo da lei, ou seja, a cultura punitiva mesma, com notória função moralista e discriminatória. Não obstante, pouco ou nada percebem o quanto esta força pode reverter-se em um efeito rebote de deslegitimação dos meios midiáticos pela ineficiência em suportar efeitos sociais satisfatórios duradouros. Arriscam, nesta direção, a se enfraquecer e ao revés alimentar as condições para o agravamento da instabilidade social (INSTITUTO BRASILEIRO DE CIÊNCIAS CRIMINAIS, 2010, p. 13).

Os meios de comunicação de massa, portanto, regulam os modos de condicionamento ao consumo de uma realidade fabricada, e quando jogam com a manipulação do sentimento de insegurança, tornam-se cúmplices privilegiados dos massacres protagonizados pelo poder punitivo (ZAFFARONI, 1991). Condicionamento criminológico que, no caso em questão, vale-se de imagens conjugadas aos discursos político-criminais repressores, exatamente para criar uma demanda midiática para amparar os receios públicos (GARLAND, 2008).

Por essa forma de exibição de acontecimentos, o sistema imagético criado regula as identificações sociais dentro da esfera das aparências, adequada à comunicação social e ao mercado de consumo. Administra o ethos (no sentido de costumes) e simula padrões consensuais de conduta. Trata-se, em suma, de produção e gestão de uma sociabilidade artificiosa, encenada num novo tipo de espaço público, cuja forma principal é a do espetáculo (SODRÉ, 2006).

A partir do que nos interessa quanto à campanha “Crack, nem pensar", como dito, percebem-se claramente os elementos de seleção e interpretação utilizados como filtro das imagens, em especial associadas a um retrato chocante produzido pelo uso da droga, apenas preocupadas em causar impacto e envolver o público, distante dos reais motivos envolvidos nos (ab)usos do crack.

Outra dimensão extremamente interessante, por um lado, é iluminada quando se examina, ao mesmo tempo que se apela a “nem pensar” na questão do crack, qual é o foco a se pensar atribuído pelo jornal do Grupo RBS, precisamente no mesmo instante que traz a campanha. Procura-se dirigir a publicidade - como se entregando diretamente o negativo da própria imagem da campanha “Crack, nem pensar” - ao tipo de interesse real a que está a serviço: difunde-se, de fato, o que deveríamos pensar: “PenseImóveis”, “PenseCarros” (Figura 7). 
Figura 7 - Publicidade

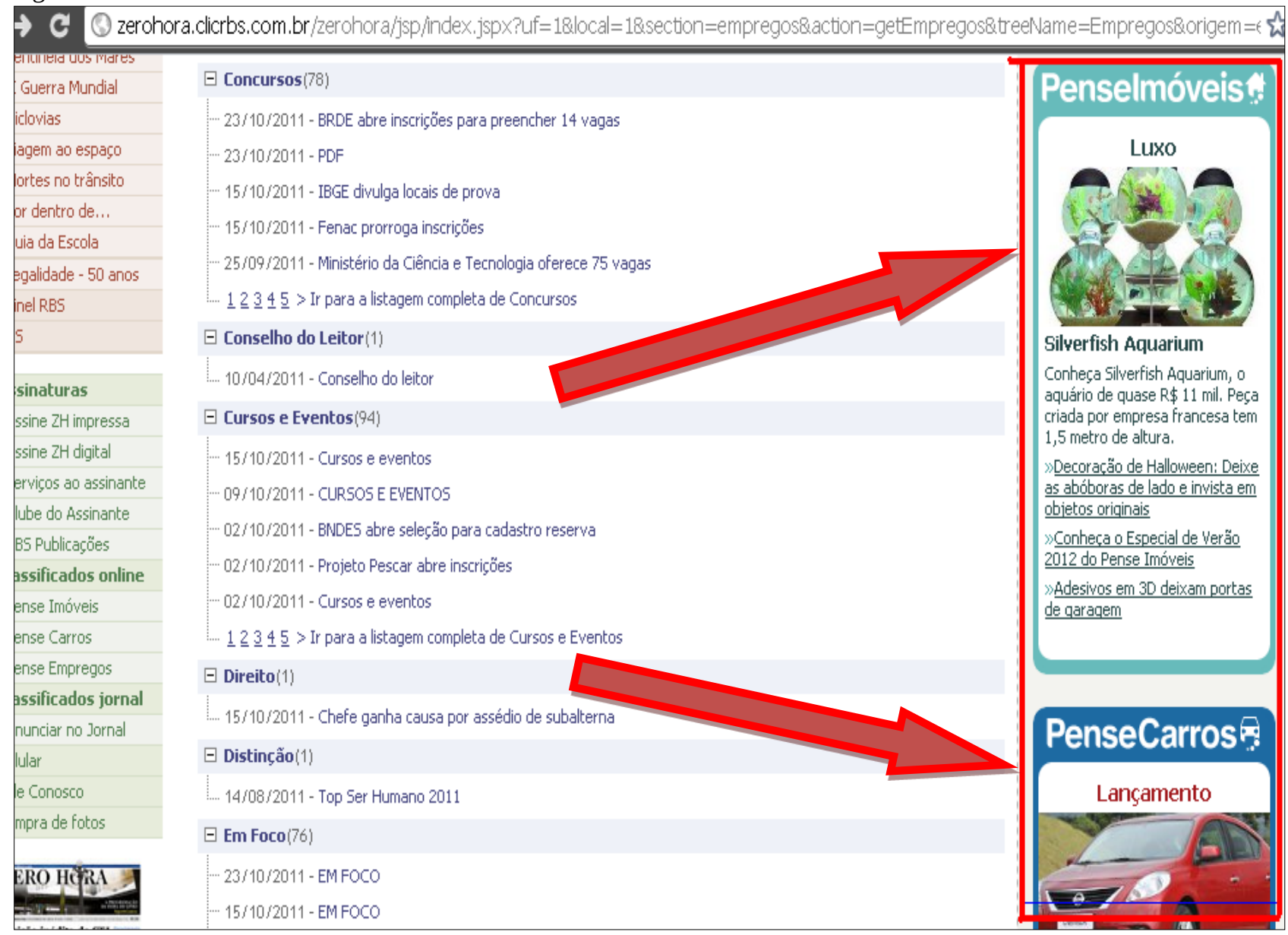

Fonte: ZERO HORA, 2011, grifo nosso.

Pensar, afinal, é existir por meio do consumo, perspectiva que naturalmente não abre espaço para os consumidores falhos refugados pelo capital (BAUMAN, 1998, p. 106 et seq.). A vida matizada e mimetizada pelo consumo ${ }^{5}$ expõe aquilo que realmente importa, afirma em que(m) vale se preocupar verdadeiramente, ou seja, aponta aqueles que nem sequer são passíveis de qualquer sentido a refletir.

Se o uso de drogas é característico das mais distintas culturas e povos desde a antiguidade (ESCOHOTADO, 1995), na sociedade atual a informação sobre elas foi quase que plenamente capturada pelo pânico social extensivo do processo de criminalização. A cruzada moral está mais afeita a transformar o medo da criminalidade em risco real (YOUNG, 2002), rebaixando qualquer complexidade em função de uma duradoura atuação política e simbólica de controle do crime

\footnotetext{
5 “[... Mais do que nunca a propaganda persegue um único fim banal: fazer as mercadorias falarem um 'compra-me’ irresistível. Porém, precisamente por causa disso, tal 'compra-me’ se configura em um ponto crucial em torno do qual toda uma nova cultura comunicativa é formada. Em outras palavras, quanto mais desenfreadamente a propaganda persegue seu objetivo final, tanto menos se absorve nele sem deixar vestígios.” (TÜRCKE, 2010, p. 24).
} 
(COHEN, 2002). À criminologia midiática, enfim, importa menos uma realidade a ser pensada que um alvo a ser temido.

\section{CONCLUSÃO}

Novamente será o próprio Carl Hart a indicar uma conclusão mais que objetiva: "uma política de drogas [deve ser] baseada em fatos, não em ficção”. Do contrário, lembrando Goya, será o sono de alguma razão que criará os mais terríveis monstros, nada tardando a repressão policial a delinear o grupo social preferido a assumir este posto.

O presente artigo, assim, procurou apresentar, mesmo que de maneira breve, porém incisiva, uma compreensão adequada da relação entre mídia e política criminal de drogas a partir da campanha “Crack, nem pensar” do Grupo RBS. Dessa forma, apresentamos as estratégias discursivas na montagem do campo simbólico midiático pronto a alimentar o proibicionismo em matéria repressiva e uma realidade social de exclusão.

Em jogo, a obviedade da criação de uma campanha publicitária ancorada na legitimação para o público das agências penais (polícia, Judiciário). Por meio de estereótipos criados pela dissociação da realidade científica, novamente grupos sociais vulnerabilizados são expostos à repressão. Postura que envolve:

[...] a destruição da comunidade [...]. E a conduta atuarial de policiamento, zoneamento e prevenção diferenciais ajuda a manter esta situação; com efeito, na medida em que desloca o crime das áreas bem protegidas de classe média para as áreas menos protegidas das camadas mais baixas da classe trabalhadora [...]. Um processo atuarial de exclusão e administração de riscos que se acopla a um mecanismo cultural de produzir bodes expiatórios: a criação de um outro desviante segregado espacial e socialmente (YOUNG, 2002, p. 43).

De modo resumido, acompanhando Wacquant (2008, p. 50-51), surgem três consequências diretas desta política de repressão às drogas: (a) a criação permanente de um subproletariado que exacerba socioespacialmente a exclusão, implicando o abandono do lugar e da sua população. Ademais, (b) por meio deste tipo de campanha naturaliza-se a nocividade de certos espaços, circunscrevendo "falsamente ao próprio gueto um problema que tem raízes na divisão racial da política, da cidade e do Estado”. Por último, de fato, (c) a designação pejorativa e a perseguição contínua a este grupo marginalizado - underclass - como indivíduos fracassados, germes representativos da "maldição que aflige os outros”, desativa a inovação das responsabilidades coletivas em relação a este “purgatório urbano simbolizado”, restando apenas lutar para que outros lá não sucumbam, levando ao extremo abandono político e ao próprio extermínio. 
A campanha procura estabilizar a classe média em seu modelo idealizado de vida, envolvendo-a como vítima que padece nas mãos dos criminosos. A apresentação deles, assim, confere forma a inflexão emocional à experiência do crime, amplamente ditada por seus valores e não pelo fenômeno em si (MILLS, 1976). Para tanto, criam-se redes de exclusão. Formam-se tensões no imaginário, tanto no oficial codificado e manifesto quanto naquele recalcado, “selvagem” e latente. Lógicas condominiais, para além da metáfora física, passam a povoar a pretensão idílica de vida tranquila na selva suburbana (YOUNG, 2002).

Medo e o mal-estar, como sintomas de um tempo de ilusão (BIRMAN, 2007), acabarão cedo ou tarde a descambar para o círculo perverso da repressão. Que isto se materialize por meio da espetacularização midiática de formas de vida abjetas, em que a droga é apenas seu pretexto moralizante, é apenas o acólito de uma sociedade que, nem ao custo de muita lucidez, parece antever a vergonha de sua condição.

\section{REFERÊNCIAS}

ALEXANDER, Michelle. El color de la justicia: la nueva segregación racial en Estados Unidos. Traducción Carmen Valle y Ethel Odriozola. New York: The New Press, 2017.

ALVES, Marcelo Mayora. Entre a cultura do controle e o controle cultural: um estudo sobre as práticas tóxicas na cidade de Porto Alegre (Coleção Criminologias: discurso para a academia). Rio de Janeiro: Lumen Juris, 2010.

ANDRADE, Vera Regina Pereira de. Pelas mãos da criminologia: o controle penal para além da (des)ilusão. Rio de Janeiro: Revan, 2012.

AZEVEDO, Rodrigo Ghiringhelli de. Sociologia da administração da Justiça. In: LIMA, Renato Sérgio de; RATTON, José Luiz; AZEVEDO, Rodrigo Ghiringhelli de (org.). Crime, segurança e justiça no Brasil. São Paulo: Contexto, 2014.

BARAK, Gregg. Newsmaking criminology: reflections of the media, intellectuals, and crime. Justice Quartely, vol. 5, no. 4, 1988.

BARASCUT, Paul. Violências midiáticas. In: Revista Famecos: Mídia e violência do imaginário, Porto Alegre, n. 29, 2006, p. 135-138.

BARATTA, Alessandro. Criminologia crítica e crítica do direito penal: introdução à sociologia do direito penal. Tradução Juarez Cirino dos Santos. 3. ed. Rio de Janeiro: Revan/ICC, 2002.

BASTOS, Francisco Inácio; BERTONI, Neilane (org.). Pesquisa Nacional sobre o Uso de Crack: quem são os usuários de crack e/ou similares do Brasil? Quantos são nas capitais brasileiras? Rio de Janeiro: ICICT/FIOCRUZ, 2014. 
BATISTA, Nilo. Mídia e sistema penal no capitalismo tardio. In: Revista Discursos Sediciosos. V. 12. Rio de Janeiro: Revan, 2002. Disponível em: http://bit.ly/2VSkGf5. Acesso em: 10 dez. 2018.

BATISTA, Vera Malaguti. Difíceis ganhos fáceis: drogas e juventude pobre no Rio de Janeiro. 2. ed. Rio de Janeiro: Revan, 2003.

BAUMAN, Zygmunt. O Mal-Estar da Pós-Modernidade. Tradução Mauro Gama e Cláudia Martinelli Gama. Rio de Janeiro: Zahar, 1998.

BIRMAN, Joel. Mal-estar na atualidade: a psicanálise e as novas formas de subjetivação. Rio de Janeiro: Editora Civilização Brasileira, 2007.

BOITEUX, Luciana. Drogas e cárcere: repressão às drogas, aumento da população penitenciária brasileira e alternativas. In: SHECAIRA, Sérgio Salomão (org.) Drogas. Uma nova perspectiva (Monografias; 66). São Paulo: IBCCRIM, 2014.

BOURDIEU, Pierre. Sobre a televisão. Rio de Janeiro: Zahar, 1997.

BROWNSTEIN, Henry H. The Media and the Construction of Randon Drug Violence. In:

FERREL, Jeff; SANDER, Clinton (ed.). Toward Cultural Criminology. Lebanon: Northeastern University Press, 1995. p. 45-79.

BUDÓ, Marília. Velhas e novas mídias: estratégias de acesso da crítica criminológica ao discurso público sobre o crime. Panóptica, vol. 11, n. 2, p. 471-501, jul./dez. 2016.

BUSTOS RAMÍREZ, Juan. Coca-Cocaína: entre el derecho y la guerra. Bogotá: Temis, 1996.

CARVALHO, Salo de. O papel dos atores do sistema penal na era do punitivismo: o exemplo privilegiado da aplicação da pena. Rio de Janeiro: Lumen Juris, 2010.

COHEN, Stanley. Folk Devils and Moral Panics: the creation of the mods and rockers. 3rd. ed. London: Routledge, 2002.

CONTRERA, Malena Segura. Mídia e pânico: saturação da informação, violência e crise cultural na mídia. São Paulo: Annablume/Fapesp, 2002.

DOMANICO, Andrea. “Craqueiros e cracados: bem vindo ao mundo dos nóias!” Estudo sobre a implementação de estratégias de redução de danos para usuários de crack nos cinco projetospiloto do Brasil. 2006. Tese (Doutorado em Ciências Sociais) - Universidade Federal da Bahia, Salvador, 2006.

DUALIBI, Lígia Bonacim; RIBEIRO, Marcelo; LARANJEIRA, Ronaldo. Perfil dos usuários de cocaína e crack no Brasil. Unidade de Pesquisa em Álcool e Drogas (UNIAD). Departamento de Psiquiatria. Universidade Federal de São Paulo (UNIFESP). 2007. Disponível em: http://bit.ly/2UEQKGO. Acesso em: 1 jul. 2018.

ESCOHOTADO, Antonio. Aprendiendo de las drogas: usos y abusos, prejuicios y desafios. Barcelona: Anagrama, 1995. 
EUROPEAN MONITORING CENTER FOR DRUGS ADDICTION (EMCDDA). 2010 Annual report on the state of drugs problem in Europe. Lisboa, novembro 2010. Disponível em: http://bit.ly/2VWDxWB. Acesso em: 1 jul. 2018.

FERRELL, Jeff; HAYWARD, Keith; YOUNG, Jock. Cultural Criminology: an invitation. London: Sage, 2008.

GARLAND, David. A cultura do controle: crime e ordem social na sociedade contemporânea. Tradução André Nascimento. Rio de Janeiro: Revan, 2008.

GIRARD, René. O bode expiatório. São Paulo: Paulus, 2004.

GONZÁLEZ ZORRILA, Carlos. Drogas y cuestión criminal. In: El Pensamiento Criminológico II - Estado y control. Bogotá: Temis, 1983. p. 179-220.

GUILHON, Orlando José Ferreira. Comunicação pública e violência urbana. In: NEPOMUCENO, Carlos; ROCHA, José Carlos; GUILHON, Orlando José Ferreira; SANTOS, Tião (org.). Mídia e violência urbana no Brasil. Brasília: UNESCO/Viva Rio, 2007. p. 37-62.

HARCOURT, Bernard. Illusion of Order: The False Promise of Broken Windows Policing. Cambridge: Harvard University Press, 2004.

HART, Carl. Um preço muito alto: a jornada de um neurocientista que desafia nossa visão sobre as drogas. Tradução Clóvis Marques. 1. ed. - Rio de Janeiro: Zahar, 2014.

HOUDAYER, Hélène. Droga e publicidade: uma visão simbólica. In: Revista Famecos: Mídia e violência do imaginário, Porto Alegre, n. 29, 2006, p. 99-106.

INÁCIO, Mariana Secorun. Crack e o conflito com a lei: análise das decisões proferidas pelo Tribunal de Justiça do Estado do Rio Grande do Sul pelo ano de 2008. 2009. Dissertação (Mestrado em Ciências Criminais) - Faculdade de Direito, Pontifícia Universidade Católica do Rio Grande do Sul, Porto Alegre, 2009.

INSTITUTO BRASILEIRO DE CIÊNCIAS CRIMINAIS (IBCCRIM). Boletim, São Paulo, ano 18, n. 12 - julho de 2010.

KARAM, Maria Lúcia. Proibições, Riscos, Danos e Enganos: as Drogas Tornadas Ilícitas. Escritos sobre a Liberdade. Vol. 3. Rio de Janeiro: Lumen Juris, 2009.

MILLS, Wright. A Nova Classe Média [White Collar]. 2. ed. Tradução Vera Borda. Rio de Janeiro: Jorge Zahar, 1976.

OLMO, Rosa del. La Cara Oculta de la Droga. Bogotá: Temis, 1998.

PETUCO, Denis Roberto da Silva. Entre imagens e a palavra: o discurso de uma campanha de prevenção ao crack. 2011. Dissertação (Mestrado em Educação) - Universidade Federal da Paraíba, João Pessoa, 2011. 
PINTO NETO, Moysés da Fontoura. O rosto do inimigo: um convite à desconstrução do direito penal do inimigo. Rio de Janeiro: Lumen Juris, 2012.

ROSA, Pablo Ornelas. Drogas. In: CARLEN, Pat; FRANÇA, Leandro Ayres (org.). Criminologias Alternativas. Porto Alegre: Canal Ciências Criminais, 2017. p. 259-270.

SODRÉ, Muniz. Sociedade, mídia e violência. 2. ed. Porto Alegre: Sulina, 2006.

THOMPSON, John B. A mídia e a modernidade: uma teoria social da mídia. Petrópolis: Vozes, 1995.

TÜRCKE, Christoph. Sociedade excitada: filosofia da sensação. Tradução Antonio A. S. Zuin, Fabio A. Durão, Francisco C. Fontanella e Mario Frungillo. Campinas: Editora da Unicamp, 2010.

VALOIS, Luís Carlos. O direito penal das drogas. Belo Horizonte: D’Plácido, 2017.

WACQUANT, Loïc. As duas faces do gueto. São Paulo: Boitempo, 2008.

XIBERRAS, Martine. Mídia e violência do imaginário. In: Revista Famecos: Mídia e violência do imaginário, Porto Alegre, n. 29, 2006, p. 87-98.

YOUNG, Jock. A sociedade excludente: exclusão social, criminalidade e diferença na modernidade recente. Tradução Renato Aguiar. Rio de Janeiro: Revan, 2002.

ZAFFARONI, Eugene Raul. Em busca das penas perdidas: a perda da legitimidade do sistema penal. Tradução Vania Romano Pedrosa e Almir Lopez da Conceição. Rio de Janeiro: Revan, 1991.

ZAFFARONI, Eugene Raul. La palabra de los muertos. Conferencias de criminología cautelar. Buenos Aires: Ediar, 2011.

ZERO HORA (Jornal). Porto Alegre. Edição de 30.05.2009a.

ZERO HORA (Jornal). Porto Alegre. Edição de 31.05.2009b.

ZERO HORA (Jornal). Porto Alegre. Edição de 02.07.2009c.

ZERO HORA (Jornal). Porto Alegre. Edição de 30.07.2009d.

ZERO HORA (Jornal). Porto Alegre. Edição de 20.12.2009e.

ZERO HORA (Jornal). Porto Alegre. Edição de 15.11.2009f.

ZERO HORA (Jornal). Porto Alegre. Edição de 23.10.2011. 
Guilherme Michelotto Böes

Doutor em Ciências Sociais, Mestre em Ciências Criminais, Integrante do grupo de pesquisa, cadastrado no CNPq, “Criminologia, Cultura Punitiva e Crítica Filosófica”. E-mail: guilherme.boes@gmail.com

Augusto Jobim do Amaral

Doutor em Altos Estudos Contemporâneos (Ciência Política, História das Ideias e Estudos Internacionais Comparativos) pela Universidade de Coimbra (Portugal); Doutor, Mestre e Especialista em Ciências Criminais pela Pontifícia Universidade Católica do Rio Grande do Sul (PUCRS). Entre os anos de 2017-2018 realizou estudos de Pós-Doutorado na Universidad de Málaga (UMA/España), na área de Teoría y Filosofía del Derecho, junto à Cátedra Abierta de Derecho y Literatura. Atualmente, é Professor no Programa de PósGraduação em Ciências Criminais (linha de Criminologia, Crime e Segurança Pública) e do Programa de Pós-Gradução em Filosofia, ambos da Pontifícia Universidade Católica do Rio Grande do Sul (PUCRS); lidera o grupo de pesquisa, cadastrado no CNPq, "Criminologia, Cultura Punitiva e Crítica Filosófica”. Pesquisador-convidado do Ius Gentium Conimbrigae (IGC) - Centro de Direitos Humanos da Universidade de Coimbra, tendo experiência na área de Criminologia, Direito, Filosofia Política e História das Ideias, com ênfase em temas como biopolítica, cultura penal, violência punitiva, direitos humanos, controle social e segurança pública, direito penal e processo penal.E-mail: guto_jobim@hotmail.com 